\title{
Plant Parasitic Nematodes Associated with Wheat in Northern and Middle Egypt
}

\author{
Korayem A. M., M. M. A. Youssef, M. M. M. Mohamed, U. S. Elkelany and \\ M. M. A. Hammam \\ Plant Pathol. Dept., Nematology Lab, National Res. Center,_Dokki, Giza, Egypt \\ Corresponding author email: kor_asm@yahoo.com
}

Accepted: 4 December 2018

\begin{abstract}
Distribution and identification of phytonematodes associated with wheat grown in twelve provinces of Northern and Middle Egypt were investigated during two growing seasons (2016-2017 and 2017-2018). A total of 929 soil and root samples were collected from 119 localities (villages/farms) belonging to 37 districts. Samples contained fourteen nematode genera and species viz., Aphelenchoides, Criconemella, Ditylenchus, Helicotylenchus, Heterodera, Hirschmanniella oryzae, Hoplolaimus, Longidorus, Meloidogyne, Pratylenchus, Rotylenchulus reniformis, Tylenchorhynchus, Ttylenchus and Xiphinema. The stunt nematodes (Tylenchorhynchus spp.), the rootlesion nematodes (Pratylenchus spp.), the spiral nematodes (Helicotylenchus spp.) and the cyst nematodes (Heterodera spp.) were the most frequent nematodes in all samples. The stunt nematodes had the highest occurrence with $47.4 \%$, population density with 48.2 and prominence value with 33.2. The root-lesion nematodes ranked the second after Tylenchorhynchus spp., in terms of frequency of occurrence (13.77\%), while the cyst nematodes had the second order after the stunt nematodes, in terms of population density (24.8) and prominence value (5.4). The spiral nematodes occupied the third rank, in terms of frequency of occurrence $(5.5 \%)$, and the last rank in terms of both of population density and prominence value ( 9 and 2.1, respectively).
\end{abstract}

Keywords: Distribution, Phytonematodes, Wheat, Egypt, Population density

\section{INTRODUCTION}

Wheat, Triticum aestivum L. is the most important cereal crop in Egypt, as it is the principle source of bread which form an essential part of Egyptian food of low cost protein, lipids and amino acids. Wheat is cultivated in Egypt on about 1.37 million hectares producing about 9 million tons (FAOSTAT, 2016). However, Egypt is the world's largest wheat importer with average of 10 million tons per year, (FAO, 2012), subjected to increase with increasing Egyptian population. Increasing yield of cultivated area is possible through recognition nematode problems affecting wheat production and application suitable methods of their management.

More than 33 phytonematodes were found in the rhizosphere of wheat growing in all regions of the world (Ibrahim, 2011). The most important nematodes affecting wheat are the cereal cyst nematodes, Heterodera avenae, the root lesion nematodes, Pratylenchus spp., the seed gall nematode, Anguina tritici, the root-knot nematodes, 
Meloidogyne spp. and the stem nematode, Ditylenchus dipsaci (Kort, 1972; Griffin, 1984; Swarup and Sosa-Moss, 1990; Rivoal and Cook, 1993; Nicol et al., 2003; McDonald and Nicol, 2005; Nicol and Rivoal, 2008; Bockus et al., 2009; Smiley and Nicol, 2009; Dawabah et al., 2010).

The cereal cyst nematodes (H.avenae, H.filipjevi, H.latipons) are considered one of the major disease agents of wheat throughout the world. They are found in many countries of Europe, Asia, Africa, Australia, North and South America (Meagher, 1972and 1977; Evans and Rowe, 1998; Smiley et al., 2005; Nicol and Rivoal, 2008; Smiley and Nicol, 2009; Ibrahim et al., 1982 and 2017). Loss in wheat yield caused by the cereal cyst nematodes was ranged between 15-20\% in Pakistan (Maqbool 1988), 40-92\% in Saudi Arabia (Ibrahim et al., 1999), 23-50\% in Australia (Meagher, 1972), 26-96\% in Tunisia (Namouchi - Kachouri et al., 2008), and about 10\% in Western USA (Smiley and Nicol, 2009). The root-lesion nematodes (Pratylenchus spp.) are also, considered important pests of wheat. At least, eight species are parasites of wheat (Nicol et al., 2003; Castillo and Volvas, 2007).

Four species, P.crenatus, P.neglectus, P.penetrans and P.thornei occur throughout the cereal producing regions in Australia, Europe, India, Mediterranean Basin, Middle East, West Asia, North Africa and North America (Nicol and Rivoal, 2008). P.thornei is considered the most economically important species on wheat reducing yield as much as $85 \%$ in Australia, 37\% in Mexico, 50\% in Oregon (USA), 70\% in Israel (Smiley and Nicol, 2009). Wheat is also subjected of attack by the root-knot nematodes (Meloidogyne spp.) in tropics, subtropics and Mediterranean regions (Lamberti, 1979; Swarup and Sosa-Moss, 1990; Ismail and Youssef, 1992). However, their economic importance on wheat is still not well documented, especially in tropics and subtropics.

The stem nematode, $D$. dipsaci is found in many regions of the world and attacks many varieties of wheat plants. It is, however a problem on cereals in heavy soils in areas of high rainfall and cool growing seasons (Griffin, 1984). The seed gall nematode (Anguina tritici) which cause "ear- cockle" disease is distributed in India, West Asia, Jordan and Saudi Arabia (Stephan and Antoon, 1990; Stephan and AbuGharbieh, 2010). Anguina tritici was also distributed in Egypt, but successful practice of seed cleaning stopped its distribution.

In Egypt, Ibrahim et al. (1988) carried out a survey on phytonematodes associated with wheat grown in eight governorates, they detected seven nematode genera and species found in wheat rhizosphere. Few of them were of wide occurrence, and had relatively high prominence value, including the root knot nematodes (Meloidogyne spp.), the root-lesion nematodes (Pratylenhus spp.), the cyst nematode (H. avenae) and the spiral nematodes (Helicotylenchus spp.). However studies on distribution and identification of phytonematodes associated with wheat throughout Egypt are still insignificant. Therefore, the present goal of this research is to carry out an extensive survey on phytonematodes associated with wheat grown in provinces of Lower and Middle Egypt.

\section{MATERIALS AND METHODS}

Locations and sampling: Survey was performed in 12 major wheat growing provinces (governorates) during 2016-2017 and 2017-2018 seasons. These provinces are situated in northern and middle of Egypt, viz., Beheira, Kafr-El-Sheikh, Dakahlia, Gharbia, Sharkia, Ismailia, Monufia, Qalyubia, Giza, Fayum, Beni-Suef and Minya (Fig. 1). Provinces of Upper Egypt were excluded due to they have a wormer climate 
during winter season which negatively affect wheat yield, so they are categorized as low potential zone for wheat production (FAO, 2012). A total of 929 soil and root samples were collected from the rhizosphere region of wheat in 125 locations (villages) of 37 districts. Samples were collected during early vegetative period (4050 days after wheat emergence), flowering and harvest stages, were kept in plastic bags supported with data, transported to the laboratory and stored in refrigerator at 4$5^{\circ} \mathrm{C}$ until processing for nematode analysis.

Nematode extraction and identification: Soil samples were carefully mixed and 250 $\mathrm{g}$ soil from each was processed for nematode extraction by sieving and decanting method according to Christie and Perry (1951). Root samples showing lesions were cut into small pieces and left in distilled water for 2-3 days for the extraction any migratory endo-parasitic nematodes (Young, 1954). Identification of nematode genera and species was made based on the morphology of adult and larval forms (Oteifa, 1964; Golden, 1971). For the cyst nematode (Heterodera) extraction, a 100g soil airdried at room temperature was processed for cysts extraction according to methods of Shepherd (1970).

Data analysis: Population density of nematodes (PD), frequency of occurrence (FO $\%)$ and prominence values (PV) were calculated according to Norten (1978), as follows:

$\mathrm{PD}=$ Mean absolute densities of nematodes per250g in soil in all collected samples

$\mathrm{FO} \%=$ Number of samples or district containing a nematode

Total number of sample or districts

$(\mathrm{PV})=\mathrm{PD} \sqrt{ } \mathrm{FO} \% / 10$

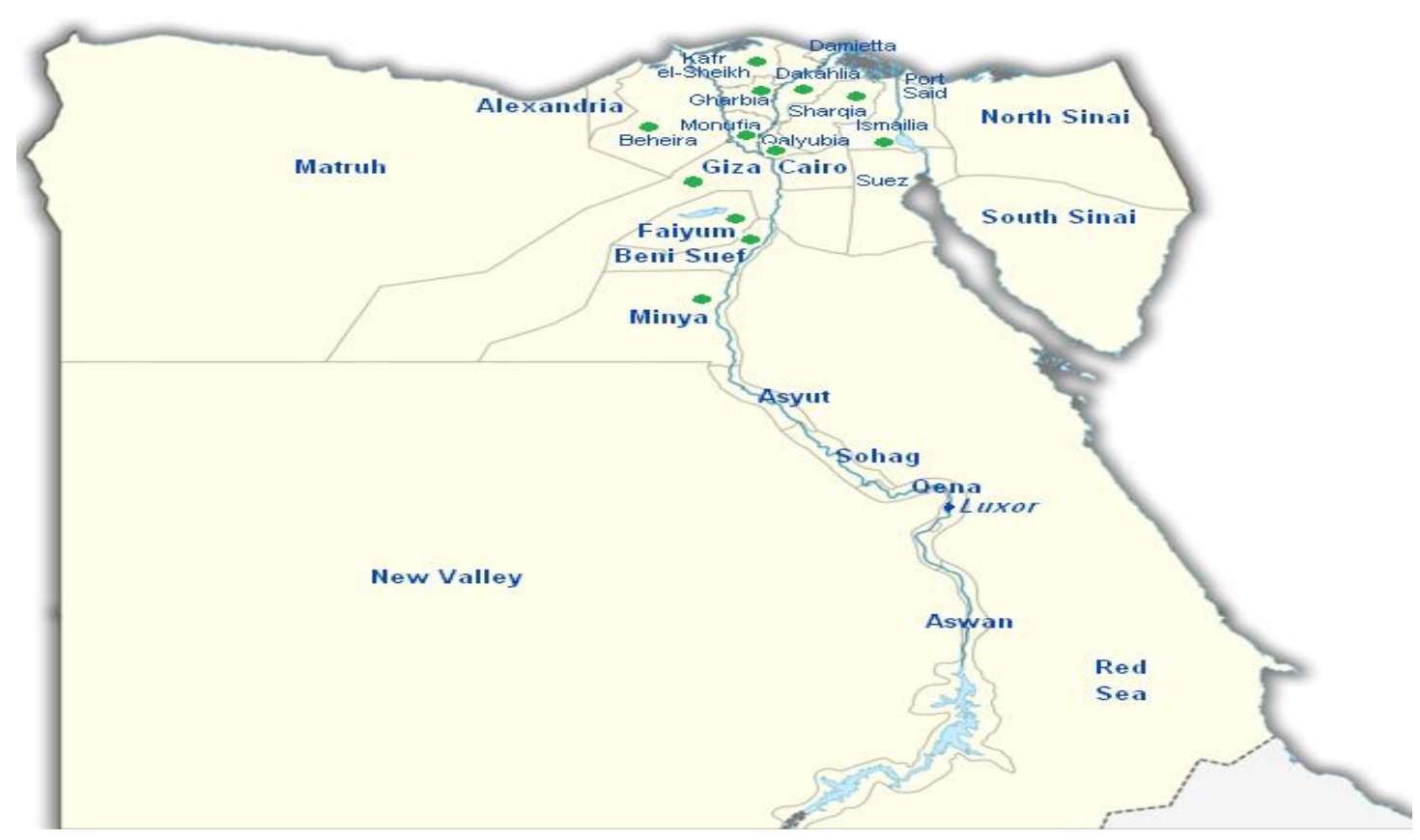

Fig 1. Map of Egypt indicating governorates in which samples were collected.

- Governorates were processed for sampling. 


\section{RESULTS}

Fourteen nematode genera and species were recovered from samples collected from 37 districts (Table 1). These were Aphelenchoides, Criconemella, Ditylenchus, Helicotylenchus, Heterodera, Hirschmanniella oryzae, Hoplolaimus, Longidorus, Meloidogyne, Pratylenchus, Rotylenchulus reniformis, Tylenchorhynchus, Ttylenchus and Xiphinema. Four of them i.e., Tylenchorhynchus, Pratylenchus, Heterodera, and Helicotylenchus were more common in the collected samples. Tylenchorhynchus was the most frequent nematode in all samples, as it occurred in all districts except of Desuk (Kafr El-Sheikh governorate), Ibsheway (Fayum governorate) and Nasser (Beni -Suef governorate) with 91.9\% FO (based on number of districts in which nematode was detected). Pratylenchus ranked the second position was detected in 26 districts with $70 \%$ FO. Helicotylenchus and Heterodera had a relatively less occurrence with $32.4 \%$ and $29.7 \%$ FO, respectively.

Occurrence of the other nematodes genera and species were less than $13.5 \%$. Population densities (PD) of more common nematodes were_presented in Fig. (2). Tylenchorhynchus had the highest PD (48.2) followed by Heterodera (24.8), Pratylenchus (9.7) and Helicotylenchus (9.0). Frequency of occurrence \% (based on number of samples in which nematode was detected relating to all samples) was presented in Fig. (3). Tylenchorhynchus had the highest FO with $47.4 \%$ followed by Pratylenchus with $13.7 \%$, Helicotylenchus with 5.5\% and Heterodera with $4.7 \%$.

Data presented in Table (2) showed the prominence value (PV) of phytonematodes genera and species found in samples collected from wheat fields in all surveyed provinces. The stunt nematode, Tylenchorhynchus spp. showed greatest PV average (33.2), followed by Heterodera (5.4), Pratylenchus (3.6) and Helicotylenchus (2.1). Highest PV of Tylenchorhynchus (90.5) was found in Beni-Suef province and the lowest (1.6) was found in Kafr-El-Sheikh province. Highest PV of Pratylenchus (15.0) was found in Beni-Suef and the lowest (0.16) in Dakahlia. Highest PV of Heterodera was (58) in Ismailia, while the highest PV of Helicotylenchus was found in Giza province (12.0).

\section{DISCUSSION}

As mentioned, survey of phytonematodes associated with wheat grown in 12 governorates of Egypt indicated the presence of fourteen_nematode genera and species associated with wheat plants. Only four of them viz. Tylenchorhynchus spp. Pratylenchus spp., Helicotylenchus spp., and Heterodera spp. had the highest frequencies of occurrence (FO\%), population densities(PD) and prominence values (PV). The stunt nematodes (Tylenchorhynchus spp.) were of wide spread occurrence in all collected samples. However, their economic importance on wheat still is not determined in Egypt and needs many studies to determine population density at which economic damage occurs, especially, they are not listed as a pathogen to wheat in the growing areas of wheat worldwide. The root lesion nematodes (Pratylenchus spp.) were also abundant in the collected samples. Many species of these nematodes are considered important pests of wheat throughout the world. Loss in yield of wheat grown in field infested with these nematodes may reach to $85 \%$ (Smiley and Nicol, 2009). The impact of the root lesion nematodes on wheat grown under Egyptian conditions has not been carefully estimated yet. The cereal cyst nematodes (Heterodera spp.) were recovered from samples of seven provinces. Their cysts and juveniles are 
Table 1. Occurence of phytonematodes associated with wheat grown in 37 districts of Egypt.

\begin{tabular}{|c|c|c|c|c|c|c|c|c|c|c|c|c|c|c|}
\hline \multirow{2}{*}{ District } & \multicolumn{14}{|c|}{ Nematode genera } \\
\hline & Aph & Cri & Dit & Hel & Het & Hir & Hop & Lon & Mel & Pra & Rot & Tyl & Tyn & Xiph \\
\hline Rosetta & & & & & & & & & & & & + & & \\
\hline Kafr-El-Dawar & & & & & & & & & & + & & + & & \\
\hline Mahmoudia & & & & & & + & & & & + & & + & & \\
\hline Badr & & + & & & & & & & & + & & + & & \\
\hline Damanhur & & & & & & & & & & & & + & & \\
\hline Wadi-El-Natrun & & + & & & & & & & & + & & + & & \\
\hline Desuk & + & & & & & + & & & & + & & & & \\
\hline Mit-Ghamr & & & & & & + & & & & & & + & & \\
\hline Aga & & & & & & + & & & & + & & + & + & \\
\hline El-Santa & & & & & & & & & & + & & + & + & \\
\hline Zifta & & & & & & & & & & + & & + & + & \\
\hline Menouf & & & & + & + & & & & & + & & + & & \\
\hline Ashmoon & & & & + & + & & & & & + & & + & & \\
\hline Sadat city & & & & + & + & & & & + & + & & + & & \\
\hline Tukh & & & & & & & & & & & & + & & \\
\hline Shibin ElQanater & & & & & & & & & & + & & + & & \\
\hline Qalyub & & & & & & & & & & & & + & & \\
\hline $\begin{array}{l}\text { El-Qanater El- } \\
\text { Khayerya }\end{array}$ & & & & & & & & & & + & & + & & \\
\hline Belbeis & & & & & & & & & & + & & + & & \\
\hline New Salhia & + & & + & + & & & & & & + & & + & & + \\
\hline
\end{tabular}


Table 1. (continued)

\begin{tabular}{|c|c|c|c|c|c|c|c|c|c|c|c|c|}
\hline Abu Suweir & & & + & & + & & & & + & & + & + \\
\hline Al Qassasein & + & + & + & + & + & & & & + & & + & \\
\hline Fayed & & & & & + & & & + & & & + & + \\
\hline Tell-El-Kebir & + & & & & & & & & + & & + & + \\
\hline Kerdasa & & & & + & & & + & & + & & + & \\
\hline El-Manashi & & & & & & & & & + & & + & \\
\hline Al-Aiat & & & & & + & & & & + & & + & + \\
\hline Attfeih & & + & & + & + & & & & + & & + & \\
\hline Senuris & & & & & & & & & & & + & \\
\hline Tamyia & & & & + & + & & & & + & & + & \\
\hline Ibsheway & & & & & & & & & & & & \\
\hline Fayum & & & & & & & & & & & + & \\
\hline Al-Wasta & & & & + & + & & & + & + & & + & \\
\hline Baiad Al-Arab & & & & + & + & + & & & + & & + & \\
\hline Nasser & & + & & + & & & & + & & + & & \\
\hline Maghagha & & & & + & & + & & & + & & + & \\
\hline Beni-Mazar & & & & & & & & & & & + & \\
\hline
\end{tabular}

Aph. =Aphelenchoides Cri. =,Criconemella, Dit =Ditylenchus, Hel=Helicotylenchus, Het=Heterodera, Hir=Hirschmanniella oryzae, Hop=Hoplolaimus, Lon $=$ Longidorus, $\mathrm{Mel}=$ Meloidogyne, Pra= Pratylenchus, Rot=Rotylenchulus reniformis, Tyl=Tylenchorhynchus, Ty=Tylenchus and Xip=Xiphinema 


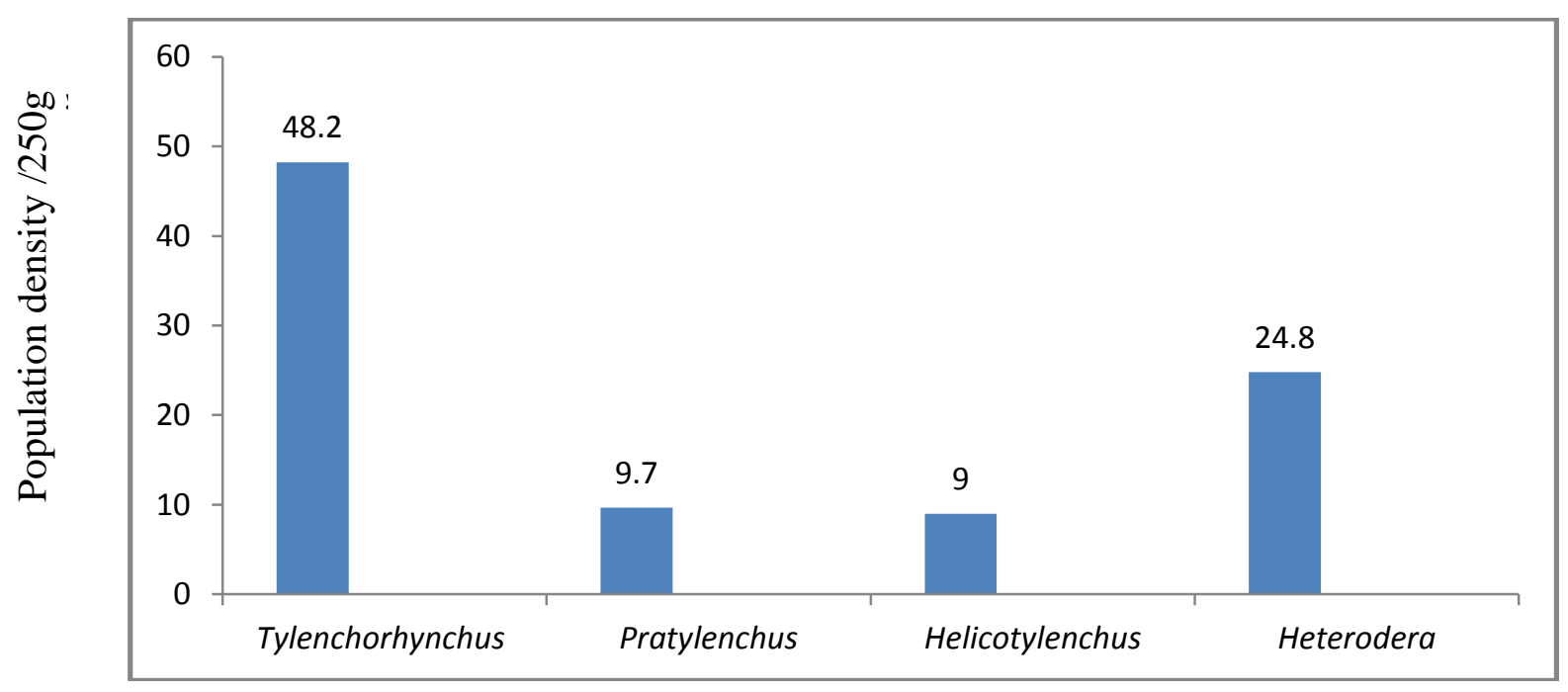

Fig.2. Population density of the more common phytonematodes associated with wheat grown in all provinces

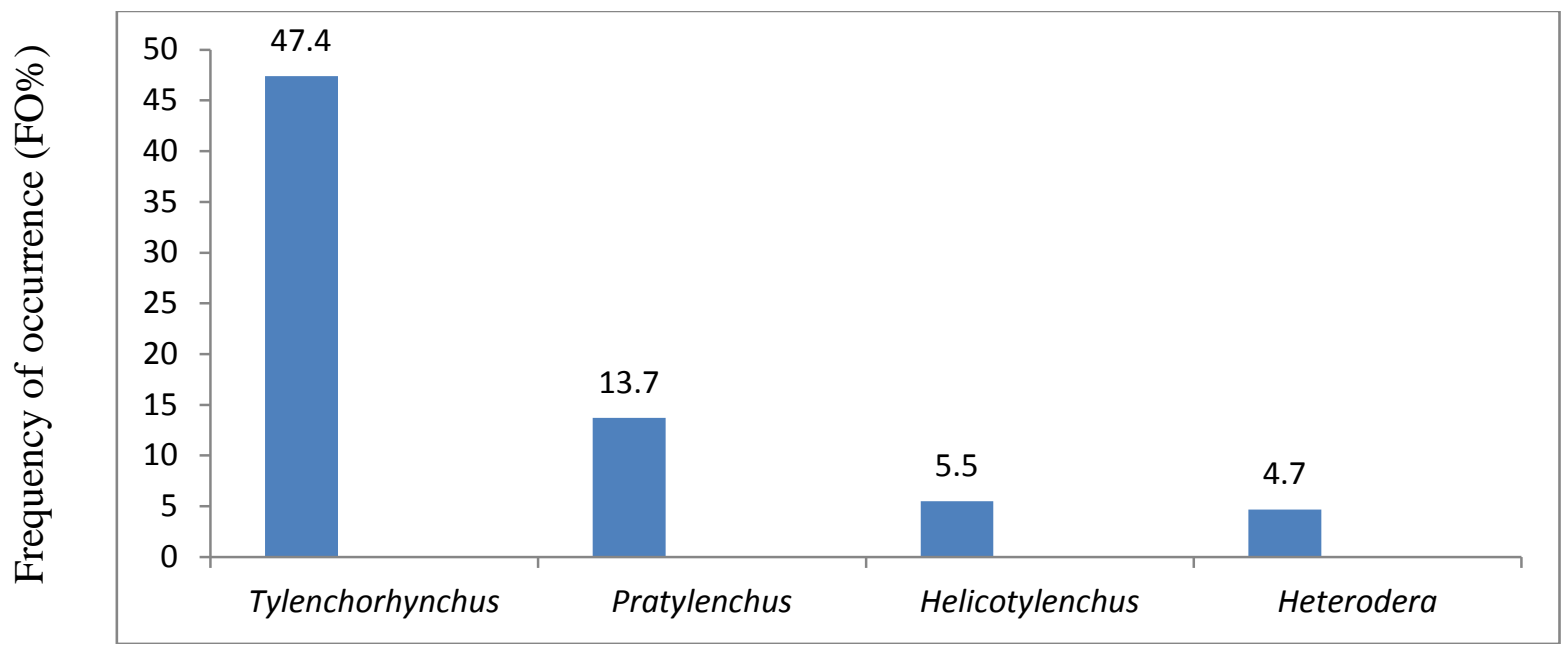

Fig.3. Frequency of the more common phytonematodes associated with wheat grown in all provinces.

now processing for identification. Heterodera avenae, H.filipjevi and H.latipons are considered one of the major disease agents of wheat throughout the world, causing loss in yield of wheat as much as $96 \%$ in Tunisia_(Namouchi-Kachouri et al., 2008), 20\% in Pakistan (Maqbool, 1988 and 50\% in Australia (Meagher, 1972). Heterodera avenae was previously detected in Beheira province (Ibrahim et al., 1982) and in Ismailia province (Baklawa et al., 2011) causing loss in wheat yield estimated by 21.6\% (Korayem and Mohamed, 2015), however, the population density which cause economic damage (economic threshold) was not studied. Therefore, many studies are needed for determining the pupation density which cause economic damage, and determining what ecological factors are suitable for disease development. The spiral nematode, Helicotylenchus spp. also occurred in some samples collected from some governorates. Effect of this nematode on wheat plants is still unknown, as well as it is not listed as pests for wheat up to now. 
Table 2. Prominence value (PV) of phytonematodes associated with wheat in twelve provinces.

\begin{tabular}{|c|c|c|c|c|c|c|c|c|c|c|c|c|c|}
\hline \multirow{2}{*}{$\begin{array}{c}\text { Phytonematodes Genera } \\
\text { \&species }\end{array}$} & \multicolumn{13}{|c|}{ Prominence value (PV) } \\
\hline & Beheira & $\begin{array}{l}\text { Kafr El- } \\
\text { Sheikh }\end{array}$ & Dakahlia & Gharbia & Sharquia & Ismailia & Monufia & Qaliyobia & Giza & Fayum & Beni-Suef & Minya & Average \\
\hline Aphelenchoides & - & 0.7 & - & - & 0.78 & 0.14 & - & - & - & - & - & - & 0.14 \\
\hline Criconemella & 0.22 & - & - & - & - & - & 0.06 & 0.1 & 0.9 & - & 1.0 & - & 0.19 \\
\hline Ditylenchus & - & 0.3 & - & - & 0.3 & 0.13 & - & - & - & - & - & - & 0.06 \\
\hline Helicotylenchus & - & - & - & - & 0.3 & 0.13 & 0.3 & - & 12.0 & 0.5 & 11.6 & - & 2.1 \\
\hline Heterodera $\left(\mathrm{J}_{2}\right)$ & - & - & - & 0.25 & - & 58 & 0.6 & - & 1.5 & 0.1 & 4.0 & 0.66 & 5.4 \\
\hline Hirschmanniella oryzae & 0.14 & 1.0 & 0.8 & - & - & - & - & - & - & - & - & - & 0.16 \\
\hline Hoplolaimus & - & & - & 0.05 & - & - & - & - & - & - & 0.14 & 0.09 & 0.02 \\
\hline Longidorus & - & - & - & - & - & - & - & - & 0.08 & - & - & - & 0.007 \\
\hline Meloidogyne $\left(\mathrm{J}_{2}\right)$ & - & - & - & - & - & - & - & - & - & - & 0.98 & - & 0.08 \\
\hline Pratylenchus & 2.3 & 2.8 & 0.16 & 0.34 & $0 . .21$ & 1.9 & 7.1 & 0.9 & 10.0 & 2.6 & 15.0 & 0.95 & 3.6 \\
\hline Rotylenculus reniformis & - & - & - & - & 1.0 & - & - & - & - & - & - & - & 0.08 \\
\hline Tylenchorhynchus & 7.1 & 1.6 & 7.7 & 17.9 & 14.8 & 10.4 & 47.0 & 40.0 & 44.0 & 47.0 & 90.5 & 70.0 & 33.2 \\
\hline Tylenchus & 0.2 & - & 0.8 & 1.0 & - & - & - & - & - & - & & - & 0.17 \\
\hline Xiphinema & - & - & - & - & - & 0.13 & - & - & 0.06 & - & - & - & 0.02 \\
\hline
\end{tabular}


In summary, our results suggested that the cereal cyst nematodes (Heterodera spp.) and the root-lesion nematodes (Pratylenchus spp.) were common in samples collected from rhizosphere of wheat grown in many locations of Egypt. These nematodes were reported as major disease agents of wheat in many wheat producing areas worldwide. Thus their identification and effects on wheat under Egyptian conditions are strongly required.

\section{ACKNOWLEDGEMENT}

The research was supported through project No. 11030134 funded by National Research Center, Dokki, Egypt.

\section{REFERENCES}

Baklawa, M.; Niere, B. and Massoud S. (2011). Damage and reproduction potentials of Egyptian populations of Heterodera avenae on wheat in Ismailia, Egypt.Annual Meeting of the Nematology Working Group, Wageningen, Netherlands.

Bockus, W.W. ; Bowden, R.L.; Hunger, R.M.; Morrill W.R.; Murray T.D. and Smiley, R.W. (2009). Compendium of wheat diseases and insects. $3^{\text {rd }}$ ed. APS Press. St. Paul. Mn. USA.

Castillo, P. and Vovlas N. (2007). Pratylenchus, Nematoda, Pratylenchidae: Diagnosis, Biology, Pathogenicity and Management. Nematological Monographs Perspectives 6: 530.

Christie, J.R. and Perry, V.G. (1951). Removing nematodes from the soil. Proc. Helminthol. Soc. Wash. 18: 106-108.

Dawabah, A.A.; Youssef, M.M.A. and Amin, A. W. (2010). Nematodes of cereals and forage crops. Pp. 773-831. In: Plant Nematology in the Arab World. AbuGharabieh W.I., Al-Hazmi A.S., Stephan Z.A. and Dawabah A.A.(eds). Arab Society for Plant Protection. Dar Wael for Publishing and Distribution, Amman, Jordan. Part 2.

Evans, K. and Rowe, J.R. (1998). Distribution and Economic Importance. PP.1-30. In: The Cyst Nematodes. Sharma S.B. (ed). Springer Science+ Business Media, Kluwer B.V. Academic Publishers.

FAO (2012). GIEWS Country Brief on Egypt (online). FAO. (http://www.fao.org/giews/country brief/country.jspa.code=Egy.

FAOSTAT (2016). Food and Agriculture Organization of the United Nations, Rome, Ialy (http://www.fao.org/faostat/en/data\#/QC.

Golden, A.M. (1971). Classification of the genera and higher categories of the order Tylenchida (Nematoda). Pp. 191-232. In: Zuckerman B.M., Mai W.F. and Rohde R.A.(Eds). Plant Parasitic Nematodes. Vol. 1, Morphology, Anatomy, Taxonomy, and Ecology, Academic Press Inc., New York.

Griffin, G.D. (1984). Nematode parasties of Alfalfa, Cereals and Grasses. Pp. 243321. In: Plant and Insect Nematodes (W.R. Nichkle, ed). Marcel Dekker Inc. Madison, Avenue, New York.

Ibrahim, A.A.M.; Al-Hazmi, A.S.; Al-Yahya, E.A.and Alderfast, A.A. (1999). Damage potential and reproduction of Heterodera avenae on wheat and barley under Saudi field condition. Nematology 1:625-630. 
Ibrahim, I.K.A. (2011). Parasitic nematodes on field crops : Diseases and Control. Manshaat El-Maaref Press, Alexandria, Egypt, pp. 63-71.

Ibrahim, I. K.A.; Handoo, Z.A. and Basyony, A.B. A. (2017). The cyst nematodes, Heterodera and Globodera species in Egypt. Pak.J. Nematol. 35: 151-154.

Ibrahim, I.K.A.; Rezk, M.A. and Ibrahim, A.A.M.(1982). Occurrence of the cyst nematodes, Heterodera avenae, H.daverti and H.rosii in northern Egypt. J. Nematol. 18(4):614 (Abstract).

Ibrahim, I.K.A.; Rezk, M.A. and Ibrahim, A.A. M.(1988). Plant parasitic nematodes associated with gramineous plant in northern Egypt. Pak. J. Nematol., 6(1) : 31-37.

Ismail, A.E. and Youssef, M.M.A. (1992). Reaction of barley and wheat cultivars to the infection of Heterodera zeae and Meloidogyne incognita. Afro-Asian J. Nematol. 3: 17-21.

Korayem, A.M. and Mohamed, M.M.M. (2015. Damage potential of Heterodera avenae on wheat growth and yield in relation to nitrogen fertilizers in Egypt. Curr. Sci. Int. 4: 515-519.

Kort, J. (1972). Nematode Diseases of Cereals of Temperate Climates. PP. 79-126. In: Economic Nematology (J.M. Webster, ed) Academic Press .London, New York.

Lamberti, F. (1979). Economic importance of Meloidogyne species in subtropical and mediterranean climates. Pp.341-357. In: Root-Knot Nematodes (Meloidogyne species): Systematics, Biology and Control. Lamberti F. and Taylor C.F. (Eds). Academic Press.

Maqbool, M.A.(1988). Present status of research on plant-parasitic nematodes in ceraels and food and forage legumes in Pakistan. Pp.173-180. In: Nematodes Parasitic to Cereals and Legumes in Temperate Semi-Arid Regions. Saxena M.C., Sikora R.A. and Spivastava J.P. (Eds). ICARDA, Aleppo, Syria.

McDonald, A.H. and Nicol, J.M. (2005). Nematode Parasites of Cereals. CABI publishing, Wallingford, UK.

Meagher, J.W. (1972). Cereal Cyst Nematode (Heterodera avenae Woll.): Studies on ecology and control In Victoria. Tech. Bull.No. 24. Victoria, Australia, Department of Agriculture.

Meagher, J.W. (1977). World dissemination of the cereal cyst nematode (Heterodera avenae) and its potential as a pathogen of wheat. J. Nematol. 9: 9-15.

Namouchi-Kachouri, N.; B'Chir M.M. and Hajji A. (2008). Effects of initial population of Heterodera avenae on wheat and barley yield components and on final nematode populations under Tunisian field conditions. Tunisian J. Plant Prot. 3: 19-26.

Nicol J.M. and Rivoal R. (2008). Global knowledge and its application for the integrated control and management of nematodes on wheat. Pp.251 -287. In: Integrated Management and Biocontrol of Vegatable and Grain Crops Nematodes. Ciancio A. and Mukerji K.G. (eds). Springer, Dordrecht. The Netherlands.

Nicol J.M.; Rivoal R.; Taylor S. and Zaharieva M. (2003). Global importance of cyst (Heterodera spp.) and lesion nematodes (Pratylenchus spp.) on cereals: Distribution, yield loss, use of host resistance and integration of molecular tools. Nematol. Monog. Perspect. 2: 1-19.

Norton, D.C. (1978). Ecology of plant parasitic nematodes. John Weiley \& Sons. New York, Toronto, Chichester. 268pp. 
Oteifa, B.A. (1964). A Taxonomic Guide to the Common Genera of Soil and Plant Nematodes with Supplement on Current Known Economic parasitic species of Egypt. Contribution of the National Research Center, Nematology Unit, Giza, Egypt.

Rivoal, R. and Cook R. (1993). Nematode Pests of Cereals. PP: 259-304. In: Plant Parasitic Nematodes in Temperate Agriculture. Evans K., Trudgill D.L. and Webster J.M.(eds). CAB International, Wallingford, UK.

Shepherd, A.M. (1970). Extraction and estimation of Heterodera. P. 23-33 in: Laboratory Methods for Work with Plant and Soil Nematodes. J.P. Southy (ed). Ministry of Agric., Fisheries and Food. Technical Bulletin 2, London,UK.

Smiley, R.W. and Nicol, J.M. (2009). Nematodes which challenge global wheat production. Pp. 171-187. In: Wheat Science and Trade, Carver B.F. (ed.), Wiley- Blackwell, Ames, IA.

Smiley, R.W.; Whittaker, R.G.; Goudie, J.A.; Easley, S.A. and Ingham, R.E. (2005). Plant parasitic nematodes associated with reduced wheat yield in Oregon: Heterodera avenae. J. Nematol. 37:297-307.

Stephan, Z.A. and Abu-Gharbieh, W.I. (2010). Cereal seed -gall nematode Anguina tritici Steinb. Pp.437-463.1n: Plant Nematology in the Arab World. AbuGharbia W.I,Al-Hazmi, A.S, Stephan, Z.A. and Dawabah A.A. (eds). Arab Society for Plant Protection. Dar Wael for Publishing and Ditribution, Amman, Jordan. Part 1.

Stephan, Z.A. and Antoon, B.G. (1990). Biotypes of Ear-Cockle Nematode, Anguina tritici in Iraq. Curr. Nematol. 1: 85-88.

Swarup, G. and Sosa-Moss, C. (1990). Nematode parasites of cereals. Pp. 109- 136. In: Plant Parasitic Nematode in Subtropical and Tropical Agriculture. Luc M., Sikora R.A. and Bridge J. (eds). CAB International, UK.

Young, T.W. (1954). An incubation method for collecting endo-migratory nematodes. Plant Dis. Reptr., 38: 794. 


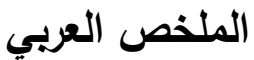

النيماتودا المتطفلة على النبات والمصاحبة للقمح فى محافظات مصر الثمالية والوسطي

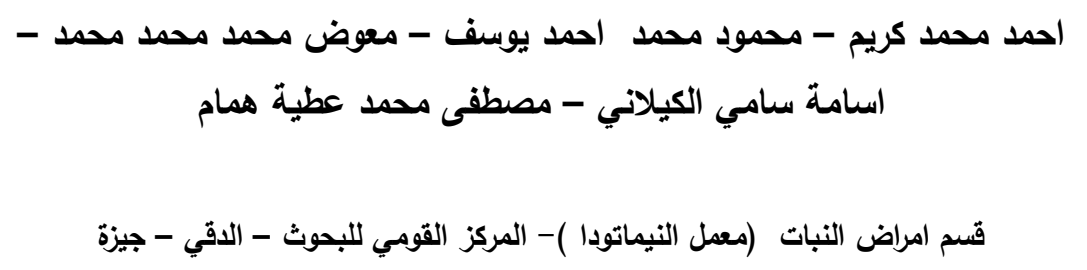

تم جمع 929 عبنة تربة ونبات من منطقة جذور القمح المنزرع فى 119 قرية فى 37 مركز من المراكز

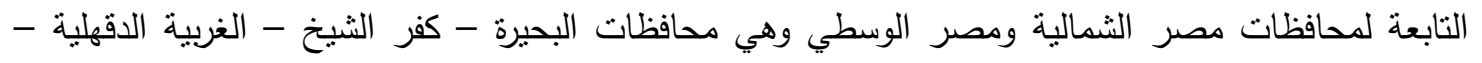

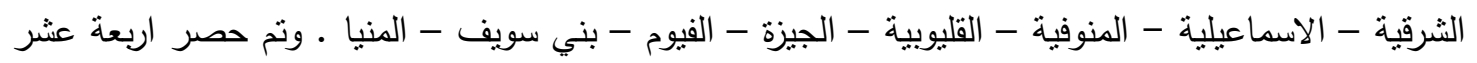

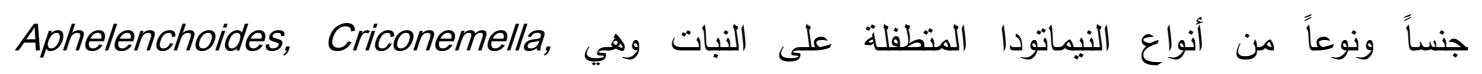
Ditylenchus, Helicotylenchus, Heterodera, Hirschmanniella oryzae, Hoplolaimus, Longidorus, Meloidogyne, Pratylenchus, Rotylenchulus reniformis, Tylenchorhynchus, Tylenchus and Xiphinema واظهرت الدراسة ان نيماتودا تقزم الجذور (Tylenchorhynchus) ونيمانودا تقرح الجذور (Pratylenchus)

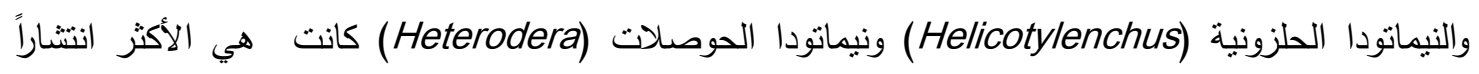

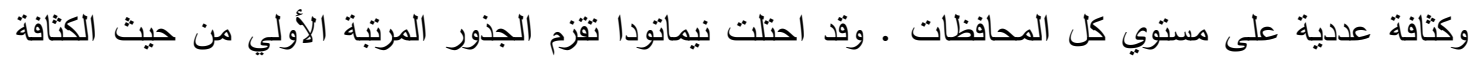

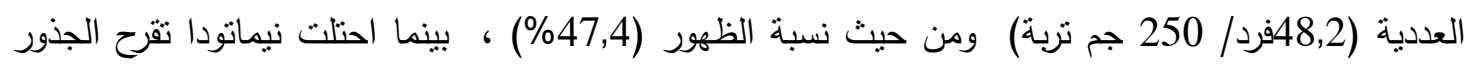

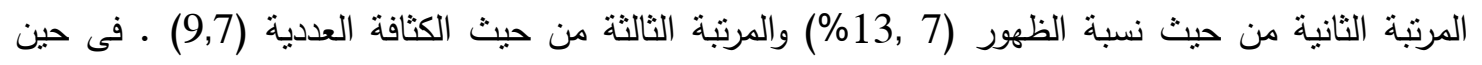

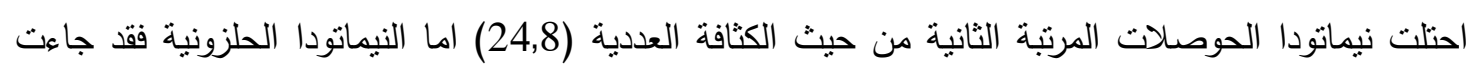
فى المرتبة الثالثة من حيث نسبة الظهور (5,5\%) والمرتبة الأخيرة من حيث الكنافة العددية (.,9) الكلمات الدالة : التوزيع - نيماتودا النبات - القمح - مصر 